\title{
JAKOŚĆ PRZEKŁADU PRAWNEGO I PRAWNICZEGO W ŚWIETLE NORMY EUROPESKIEJ PN-EN 15038 ORAZ HIPOTEZY UNIWERSALIÓW TRANSLATORYCZNYCH
} edług doniesień prasowych z powodu rażących błędów w tłumaczeniu poświadczonym kilku tysięcy stron dokumentacji śledztwa w sprawie karnej Andrieja Żukowca Sąd Rejonowy w Białymstoku nakazał ponownie przetłumaczyć wszystkie dokumenty, co polskiego podatnika kosztować będzie ponad 300 tys. złotych. Ten białoruski opozycjonista jest oskarżany przez władze Białorusi o wyłudzenie kredytów w kwocie 700 tys. dolarów. Żukowiec twierdzi, że jest niewinny, a dowody przeciwko niemu zostały spreparowane. Po odmowie ekstradycji Żukowca na Białoruś białostocka prokuratura wszczęła śledztwo, które opiera się na kserokopiach dokumentów otrzymanych od strony białoruskiej. W tłumaczeniu dokumentów zleconym sekretarz Prokuratury Apelacyjnej w Białymstoku i jej mężowi stwierdzono istotne błędy na niekorzyść Żukowca. Przykładowo w deklaracji celnej kontrahent 
z Niemiec stał się kontrahentem z raju podatkowego Wysp Dziewiczych; mylone były cyfry, a dokumenty niesygnowane otrzymywały w tłumaczeniu podpis Żukowca. Po zawiadomieniu przez Żukowca prokuratury o podejrzeniu popełnienia przestępstwa przez tłumaczy Prokuratura Okręgowa w Lublinie umorzyła śledztwo, argumentując, że „małżeństwo było przemęczone” (tłumaczom nie postawiono zarzutów, ponieważ sprawa się przedawniła) (Szymowski 2010).

Inny przykład problemu z jakością tłumaczenia, o którym donosi „Gazeta Wyborcza” w artykule Taniej nie będzie, bo zawiódł tłumacz?, dotyczy wniosku Urzędu Komunikacji Elektronicznej do Komisji Europejskiej (KE) o zgodę na możliwość wpływania na TP SA w celu obniżenia cen wymiany ruchu IP. Wniosek uzyskał negatywną opinię organu doradczego Cocon, a zdaniem prezes UKE Anny Streżyńskiej winne jest „skandalicznie złe tłumaczenie na angielski" (Poznański 2010: 32) wykonane przez tłumacza KE, w którym pojawiają się „błędy merytoryczne i pomyłki językowe w tłumaczeniu podstawowych pojęć telekomunikacyjnych, co sprawia, że dokument jest nieczytelny i wprowadza w błąd" (ibidem). Wśród błędów znalazło się pominięcie przeczenia, nieprawidłowa terminologia telekomunikacyjna w ponad 20 miejscach (np. opłata interkonektowa została przetłumaczona jako „international charge") oraz dodanie fragmentu decyzji, którego nie było w oryginale (ibidem).

Podobne przykłady można mnożyć nie tylko na gruncie polskim. Konsekwencje niskiej jakości w tłumaczeniu prawnym i prawniczym mogą być poważne zarówno dla odbiorcy tłumaczenia, jak i dla samego tłumacza. Odbiorca tłumaczenia może ponieść szkody majątkowe (np. utracone korzyści w wyniku niezawarcia umowy), a co ważniejsze - może również ponieść konsekwencje mające wpływ na jego przyszłość, zwłaszcza gdy tłumaczenie stanowi element komunikacji pomiędzy nim a organami wymiaru sprawiedliwości. Z kolei tłumacz ponosi odpowiedzialność cywilnoprawną, a konsekwencje finansowe $\mathrm{z}$ tego tytułu mogą polegać na odmowie zapłaty wynagrodzenia za tłumaczenie, jego obniżeniu czy zasądzeniu odszkodowania za poniesione szkody w razie wytoczenia powództwa przez klienta. Ponadto tłumaczom grożą konsekwencje z tytułu odpowiedzialności zawodowej w przypadku tłumaczy przysięgłych wypełniających swoje obowiązki nienależycie lub nierzetelnie Komisja Odpowiedzialności Zawodowej może orzec takie kary, jak: upomnienie, nagana, okresowe zawieszenie prawa wykonywania zawodu lub jego pozbawienie. W niektórych sytuacjach tłumacze ponoszą również odpowiedzialność karną. 
Klient (zarówno zleceniodawca tłumaczenia, jak i jego użytkownik) często nie jest w stanie ocenić jakości tłumaczenia, ponieważ na ogół zleca tłumaczenie, gdyż nie zna albo języka źródłowego, albo docelowego. Nasuwa się szereg pytań: Czym jest jakość tłumaczenia prawnego i prawniczego? Jakie są jej wyznaczniki? Jakie są sposoby zapewniania jakości? W niniejszym artykule spróbujemy na nie odpowiedzieć.

\section{Jakość jako zjawisko skalarne}

Zacznijmy od samego pojęcia jakości. W podręcznikach do marketingu jest ona często definiowana jako stopień, $\mathrm{w}$ jakim produkt lub usługa spełnia potrzeby, oczekiwania i specyfikacje klientów (Kotler i Keller 2006: 146-148). Również w literaturze przekładoznawczej podkreśla się, że tłumaczenia podlegają normom przekładowym, w tym pewnym konwencjonalnym oczekiwaniom (ang. expectancy norms) co do poprawności tłumaczenia i jego jakości. Normy te umożliwiają dokonywanie sądów wartościujących na temat tłumaczeń (Chesterman 1997: 64-65).

Klienci mogą mieć różne oczekiwania co do jakości, która jest zjawiskiem skalarnym: w przypadku tłumaczeń mówi się o: 1) draft quality (jakość robocza), 2) deliverable quality (tłumaczenie niewymagające korekty, gotowe do wysłania do klienta), 3) publishable quality (najwyższa jakość, tłumaczenie nadające się do druku). Nie zawsze klient potrzebuje najwyższej jakości; na rynku za standard uważa się deliverable quality, której zapewnienia biura tłumaczeń oczekują od współpracujących z nimi tłumaczy. Za publishable quality $\mathrm{z}$ reguły naliczana jest wyższa stawka $\mathrm{z}$ uwagi na niezbędne dodatkowe korekty tekstu.

\section{Czynniki wpływające na oczekiwania jakościowe}

Czy oczekiwania co do jakości tłumaczenia są constans bez względu na okoliczności? Na rynku tłumaczeń znane jest angielskie powiedzenie Quality, price, deadline - pick any two (Bonthrone i Fry 2004: 28), które trafnie eksponuje wpływ ceny i terminu na jakość. Nie od dziś wiadomo, że jakość kosztuje i wymaga czasu. Wiele tłumaczeń wykonuje się w trybie pilnym, superpilnym i superekspresowym (tab. $\mathrm{nr} 1$ ): 
Tabela 1. Tryby wykonywania tłumaczeń na podstawie dwóch losowo wybranych biur tłumaczeń

\begin{tabular}{|l|l|l|}
\hline \multicolumn{1}{|c|}{ Tryb } & \multicolumn{1}{c|}{ Biuro tłumaczeń A } & \multicolumn{1}{c|}{ Biuro tłumaczeń B } \\
\hline Tryb zwykły/standardowy & do 6 stron $\mathrm{z}$ dnia na dzień & do 5 stron dziennie \\
\hline Tryb pilny & od 6 do 11 stron na dzień & od 5,5 do 9 stron dziennie \\
\hline Tryb superpilny & od 11 do 15 stron na dzień & od 9,5 do 12 stron dziennie \\
\hline Tryb superekspresowy & powyżej 15 stron na dzień & $\begin{array}{l}\text { od 12,5 stron dziennie lub } \\
\text { tłumaczenie w tym samym } \\
\text { dniu }\end{array}$ \\
\hline
\end{tabular}

Szczególnie duże obciążenie dla tłumacza powoduje praca $\mathrm{w}$ trybie superpilnym i superekspresowym, w którym tłumacz pracuje pod presją czasu, tłumacząc nawet powyżej 15 stron dziennie. Z pewnością oczekiwania klienta $\mathrm{w}$ przypadku trybu superekspresowego są niższe, gdyż na pierwszy plan wysuwa się czynnik czasu, niemniej jakość takiego tłumaczenia powinna mieścić się co najmniej w dolnych granicach normy. Czynnik czasu w mniejszym stopniu dotyczy tłumaczeń poświadczonych, które najczęściej zlecane są $\mathrm{w}$ trybie zwykłym. Bez względu na tryb tłumaczenia na tłumaczu spoczywa odpowiedzialność za ustalenie podczas przyjmowania zlecenia, czy wyznaczony termin jest możliwy do osiągnięcia bez uszczerbku dla jakości. A zatem przemęczenie nie może usprawiedliwiać niskiej jakości, zwłaszcza gdy błędy $\mathrm{w}$ tłumaczeniu uniemożliwiają podejrzanemu pełne skorzystanie z przysługujących mu praw lub skutkują odrzuceniem tłumaczenia przez urząd.

\section{Normy rynkowe dotyczące przekładu specjalistycznego: PN-EN 15038 ,Usługi ttumaczeń - Wymagania dotyczące świadczenia usług"}

Norma PN-EN 15038 „Usługi tłumaczeniowe - Wymagania dotyczące świadczenia usług" jest pierwszą ogólnoeuropejską normą regulującą jakość usług tłumaczeniowych. Została przyjęta przez Europejski Komitet Normalizacyjny (CEN) w 2006 r. i wdrożona przez 29 państw członkowskich w Europie, w tym przez Polskę (polską wersję normy opracowano we współpracy z Polskim Stowarzyszeniem Biur Tłumaczeń). Jej znaczenie rośnie, ponieważ coraz więcej biur tłumaczeń uzyskuje niezależną certyfikację lub przeprowadza 
samocertyfikację, a instytucje publiczne często stosują ją jako kryterium przy przetargach na obsługę tłumaczeniową.

Celem normy jest standaryzacja usługi tłumaczenia i zwiększenie jej jakości przez opracowanie „zbioru procedur i wymagań odpowiadających potrzebom rynku" w odniesieniu do szeroko rozumianych usług tłumaczeniowych (PN-EN 15036, 2006: 4). Procedury i wymagania dotyczą m.in. zasobów ludzkich i technicznych, zarządzania projektami, umów z dostawcami usług tłumaczeniowych, zarządzania relacją $\mathrm{z}$ klientem itp. W normie przyjęto kompleksowe podejście do jakości, koncentrując się na całej usłudze tłumaczeniowej, a nie na tłumaczeniu jako produkcie. W tym celu zdefiniowano podstawowe mechanizmy zapewniania jakości usługi na wszystkich jej etapach. Przykładowo, proces tłumaczenia - który powinna poprzedzić obróbka wstępna, analiza tekstu źródłowego i w razie konieczności prace terminologiczne - składa się z czterech etapów obligatoryjnych: tłumaczenia, sprawdzenia (ang. checking), weryfikacji (ang. revision) i kontroli końcowej (ang. final verification) oraz dwóch etapów fakultatywnych, o ile zostaną na żądanie klienta uwzględnione w specyfikacji usługi: redakcja (ang. review) i korekta (ang. proofreading). Poszczególne procedury zapewniania jakości w ramach procesu tłumaczenia przedstawiono na wykresie 1.

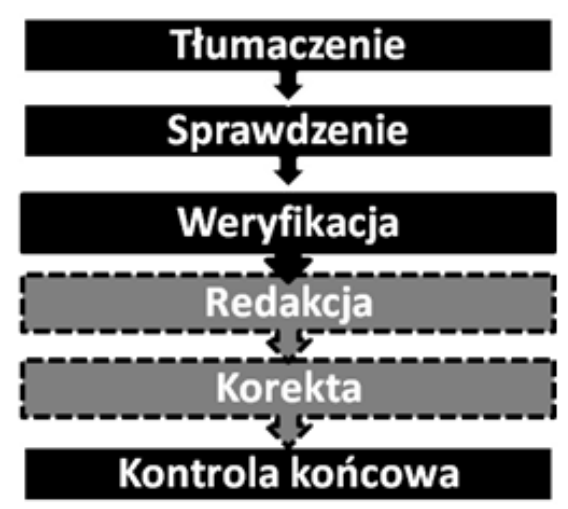

Wykres 1. Etapy procesu tłumaczenia według normy PN-EN 15038

Tłumaczenie obejmuje „przełożenie informacji z języka źródłowego na język docelowy" (PN-EN 15038, 2006: 6) zgodnie ze specyfikacją i zasadami systemu języka docelowego, w tym prawidłowe i konsekwentne stosowanie terminologii specjalistycznej, poprawność gramatyczną, leksykalną i stylistyczną, uwzględnienie aspektów kulturowych, grupy docelowej i celu tłumaczenia oraz prawidłowe formatowanie tekstu (ibidem: 11). Następnie 
tłumacz powinien sprawdzić sporządzone tłumaczenie pod kątem dokładności i zgodności ze specyfikacją ( $\rightarrow$ sprawdzenie). Kolejny etap, tj. weryfikację tłumaczenia, przeprowadza inny tłumacz, który - porównując tekst źródłowy z docelowym - ,analizuje tłumaczenie pod względem spełnienia zamierzonego celu" oraz pod kątem spójności terminologicznej, rejestru i stylu (ibidem). A zatem w tłumaczeniu wykonanym zgodnie z normą PN-EN 15038 powinny uczestniczyć co najmniej dwie osoby: tłumacz i weryfikator. Dwa kolejne etapy - redakcję i korektę - przeprowadza się na życzenie klienta. Redakcję wykonują specjaliści dziedzinowi, bez dokonywania porównań $z$ oryginałem, „w celu oceny, czy dane tłumaczenie spełnia przypisany mu cel” (ibidem). Natomiast korekta polega na ostatecznym sprawdzeniu tłumaczenia przed publikacją. Proces tłumaczenia wieńczy kontrola końcowa, w ramach której dostawca usługi tłumaczeniowej sprawdza, czy jest ona zgodna ze specyfikacją.

Największą zaletą normy jest usankcjonowanie weryfikacji jako niezbędnego elementu zapewniania jakości (Biel 2011). Obowiązkowa weryfikacja tekstu przez innego tłumacza, czyli zasada dwóch par oczu, pozwala na bardziej obiektywną ocenę jakości tekstu docelowego. Należy jednak pamiętać, że norma oferuje holistyczne podejście do jakości tłumaczenia na wszystkich jego etapach. Jak zauważa Martin, o jakości nie decyduje wyłącznie weryfikacja, ale wszystkie czynności związane z usługą tłumaczenia, w tym rekrutacja, szkolenia i zasoby techniczne (2007: 61-62). Norma ułatwia dostawcom usług tłumaczeniowych wprowadzanie rozwiązań i procedur, dzięki którym mogą zapewnić tłumaczenia odpowiedniej jakości, z kolei klientom umożliwia identyfikację takich dostawców.

Jak już podkreślono, norma skupia się na procesie świadczenia usługi, a nie na tekście docelowym. Ponieważ odnosi się do całej branży tłumaczeń specjalistycznych, została sformułowana z odpowiednim stopniem ogólności, więc stosunkowo niewiele mówi o wyznacznikach jakości samego tłumaczenia, którymi zajmiemy się w dalszej części artykułu.

\section{Dwuwymiarowość tłumaczeń: relacja ekwiwalencji i relacja dopasowania tekstowego}

Hipoteza uniwersaliów translatorycznych (ang. translation universals) wysunięta przez Monę Baker zakłada, że tłumaczenia wykazują szereg wspólnych cech niezależnie od pary językowej czy rodzaju tekstu. Cechy te wynikają ze specyfiki procesu tłumaczenia i obejmują: 
- eksplicytację: tendencję tłumaczy do precyzowania (wyrażania explicite) znaczenia, które w tekście źródłowym jest implicite,

- uproszczenia i eliminację wieloznaczności: tendencję do upraszczania przekazu tekstu źródłowego lub jego języka,

- normalizację i sanitację: tendencję do przesadnego odzwierciedlania typowych cech języka docelowego oraz eliminację błędów występujących w tekście źródłowym,

- spłaszczenie (ang. levelling-out): tłumaczenia są mniej idiosynkratyczne i bardziej podobne do siebie niż oryginały (Baker 1996: 180-185).

$\mathrm{Z}$ biegiem czasu lista uniwersaliów się rozszerzała. Chesterman dokonał ich podziału na S-uniwersalia i T-uniwersalia. S-uniwersalia dotyczą relacji ekwiwalencji (ang. equivalence relation) pomiędzy tekstem źródłowym a tekstem docelowym i obejmują takie zjawiska, jak: wydłużenie tekstu docelowego w stosunku do oryginału, sanitację, eksplicytację, prawo interferencji Toury'ego czy prawo standaryzacji Toury'ego. Z kolei T-uniwersalia mają wpływ na relację dopasowania tekstowego (ang. relation of textual fit) pomiędzy tłumaczeniem a innymi nieprzetłumaczonymi tekstami w języku docelowym i uwzględniają następujące zjawiska: uproszczenie (mniejsza różnorodność leksykalna i gęstość leksykalna), więcej elementów o wysokiej frekwencyjności, konwencjonalizacja, normalizacja, nietypowe i mniej stabilne wyrażenia frazeologiczne, niska frekwencyjność elementów specyficznych dla języka docelowego (Chesterman 2004: 6-7). Zaproponowany przez Chestermana podział adekwatnie uwypukla dwa integralne wymiary tłumaczeń specjalistycznych: dokładność przekazu informacyjnego i jego naturalność.

Pojęcie ekwiwalencji budzi w translatoryce pewne kontrowersje; niektórzy badacze uważają je za nieistotne czy wręcz szkodliwe (cf. Kenny 1998). W ostatnich latach zmienia się jednak sposób pojmowania ekwiwalencji, która przestaje być relacją identyczności, a staje się relacją podobieństwa (Tymoczko 2005: 1092). Zresztą w tłumaczeniu prawnym i prawniczym, jak podkreślają Alcaraz Varó i Hughes, osiągnięcie identyczności nie jest możliwe, m.in. z uwagi na istotne rozbieżności pomiędzy systemami prawnymi (2002). Ekwiwalencja nie polega na wierności wobec litery prawa, ale wobec ducha prawa; tłumacz powinien zadbać, aby tłumaczenie wyrażało zamierzone znaczenie i wywierało w praktyce zamierzone skutki prawne (Šarcevič 2000). W przypadku tłumaczeń prawnych i prawniczych pominięcie relacji pomiędzy tekstem źródłowym a docelowym nie jest możliwe.

Dopasowanie tekstowe, czyli naturalność tłumaczenia, bywa zaniedbywanym aspektem tłumaczeń prawnych i prawniczych. Badania korpusowe 
pokazują, że język tłumaczeń wykazuje pewne odmienne cechy niż teksty nieprzetłumaczone w tym samym języku. Stąd język tłumaczeń określa się niekiedy mianem „trzeciego języka”, „trzeciego kodu” czy „,języka hybrydowego" (ang. translationese) ze względu na interferencje z języka źródłowego oraz uniwersalia translatoryczne (cf. Biel 2010: 7). Jednym $z$ uniwersaliów jest hipoteza zaburzeń w dystrybucji elementów leksykalnych, frazeologicznych czy składniowych (Mauranen 2006: 97). Tłumacz powinien zapewnić dopasowanie tłumaczenia do języka docelowego i jego konwencji; duże rozbieżności mogą wywoływać dyskomfort u odbiorcy i mieć niekorzystny wpływ na recepcję i akceptację tłumaczenia, co może być istotne przykładowo w przypadku tłumaczeń aktów prawa unijnego.

A zatem ocena tekstu docelowego winna być dwutorowa i uwzględniać zarówno relację ekwiwalencji (dokładności tłumaczenia), jak i relację dopasowania tekstowego (naturalności tłumaczenia).

\section{Wyznaczniki jakości w tłumaczeniach prawnych i prawniczych}

Sięgnijmy do źródeł specjalistycznych, aby sprawdzić, jakie zalecenia jakościowe są w nich zawarte. Jakości tłumaczenia ustnego i pisemnego poświęcono tylko jeden artykuł we wniosku decyzja ramowa Rady w sprawie prawa do tłumaczenia ustnego i tłumaczenia pisemnego w postępowaniu karnym. Artykuł 5 stanowi dość lakonicznie, że ,tłumaczenie ustne oraz pisemne jest zapewniane w sposób gwarantujący podejrzanemu możliwość pełnego korzystania z przysługujących mu praw". Jakość jest tutaj postrzegana przez pryzmat skutku czynności tłumaczenia oraz stopnia, $\mathrm{w}$ jakim tłumaczenie spełnia potrzeby odbiorcy. Natomiast ustawa z 25 listopada 2004 r. o zawodzie tłumacza przysięgłego nakłada jedynie obowiązek wykonywania tłumaczeń „ze szczególną starannością i bezstronnością”, z zachowaniem w tajemnicy informacji uzyskanych w związku z tłumaczeniem (art. 14). Ustawa nie definiuje jednak staranności ani pojawiającej się w rocie ślubowania sumienności (art. 7). Opracowany przez PT TEPIS Kodeks tłumacza przysięgłego (2005) do szczególnej staranności dodaje bardziej konkretne kryterium wierności, uwzględnia więc relację pomiędzy tekstem źródłowym a docelowym: „Tłumacz przysięgły jest zobowiązany do wykonywania powierzonego mu tłumaczenia ze szczególną starannością, zachowując wierność wobec tekstu źródłowego zgodnie z zasadami sztuki tłumaczenia specjalistycznego i formalnoprawnymi zasadami tłumaczenia sądowego i prawniczego" ( $\$ 2$ ). Konieczność wierności tłumaczenia zarówno pod kątem treści, jak i formy 
podkreśla również karta tłumacza FIT $^{1}$, nazywając ją moralnym i prawnym obowiązkiem tłumacza (pkt 4). Oczywiście tłumaczenie wierne nie jest tożsame z tłumaczeniem dosłownym - tłumaczenie wierne może obejmować adaptację oryginału, która umożliwia oddanie formy, atmosfery i „głębszego znaczenia" oryginału w innym języku i kraju (pkt 5).

Czy staranność i wierność są jedynymi wyznacznikami jakości w tłumaczeniu prawniczym? Opisując pracę Komisji Zawodowej Tłumaczy Przysięgłych przy Ministrze Sprawiedliwości, Kubacki wymienia przykłady uchybień formalnych i merytorycznych, za które karani są tłumacze przysięgli. Najbardziej interesują nas uchybienia merytoryczne polegające „na kwestionowaniu rzetelności dokonanych tłumaczeń", które oprócz niedokładności tłumaczenia (pominięcia, nadinterpretacja, błędy merytoryczne) zawierają również kwestie poprawności językowej - „błędy w zakresie słownictwa ogólnego i specjalistycznego, gramatyki i stylistyki” (2008: 158).

Innym źródłem mówiącym pośrednio o wyznacznikach jakości jest rozporządzenie Ministra Sprawiedliwości z 24 stycznia 2005 r. w sprawie szczegółowego sposobu przeprowadzenia egzaminu na tłumacza przysięgłego. Elementy oceny tłumaczeń podczas części pisemnej egzaminu określone w rozporządzeniu prezentuje tab. 2 ):

Tabela 2. Elementy oceny części pisemnej egzaminu na tłumacza przysięgłego

\begin{tabular}{|l|l|l|}
\hline Lp. & \multicolumn{1}{|c|}{ Element oceny } & \multicolumn{1}{|c|}{ Waga } \\
\hline 1 & $\begin{array}{l}\text { Zgodność treści przekazanej w tłumaczeniu z treścią orygi- } \\
\text { nału }\end{array}$ & 10 punktów (20\%) \\
\hline 2 & Terminologia i frazeologia subjęzyka specjalistycznego & 15 punktów (30\%) \\
\hline 3 & $\begin{array}{l}\text { Poprawność gramatyczna, ortograficzna, leksykalna (leksy- } \\
\text { ka niespecjalistyczna) }\end{array}$ & 10 punktów (20\%) \\
\hline 4 & $\begin{array}{l}\text { Zastosowanie rejestru (stylu funkcjonalnego) języka właści- } \\
\text { wego dla danego rodzaju tekstu }\end{array}$ & 10 punktów (20\%) \\
\hline 5 & $\begin{array}{l}\text { Formalne zasady wykonywania tłumaczeń uwierzytelnio- } \\
\text { nych }\end{array}$ & 5 punktów (10\%) \\
\hline
\end{tabular}

Powyższa punktacja dotyczy co prawda sytuacji egzaminacyjnej, która ma na celu zweryfikowanie gotowości kandydata do wykonywania zawodu tłumacza przysięgłego, niemniej zaskakuje niska waga (20\%) przyznawana za

${ }^{1}$ Translator's Charter, 1963, Fédération Internationale des Traducteurs, http://www.fit-ift. org/en/charter.php. 
zgodność treści przekazanej w tłumaczeniu z treścią oryginału, która w tłumaczeniach prawnych i prawniczych jest priorytetem.

Jak wcześniej podkreślono, w modelu oceny tłumaczenia prawniczego trzeba uwzględnić zarówno dokładność tłumaczenia (relację do tekstu źródłowego), jak i jego naturalność (relację do innych tekstów funkcjonujących $\mathrm{w}$ języku docelowym), jednak należy im przypisać różną wagę. $\mathrm{W}$ tym celu skorzystamy ze skali oceny ryzyka zaproponowanej przez Pyma (2004), który ryzyko definiuje jako możliwość nieosiągnięcia celu tłumaczenia. Zdaniem Pyma pewne elementy tekstu i problemy tłumaczeniowe wiążą się $\mathrm{z}$ wysokim ryzykiem, inne ze średnim, a jeszcze inne z niskim. Ocena stopnia ryzyka zależy od skoposu, czyli celu tłumaczenia. Tłumacz powinien skorelować czas i wysiłki ze stopniem ryzyka, skupiając się na weryfikacji elementów wysokiego ryzyka (2004). W tłumaczeniu prawniczym, jak i w większości tłumaczeń specjalistycznych pełniących funkcję informacyjną, dokładność przekazu informacji ma fundamentalne znaczenie. Dlatego też błędy związane z dokładnością tłumaczenia będą obarczone wysokim ryzykiem, chociaż jego stopień zależy od statusu tłumaczenia, jego celu i grupy docelowej. Z najwyższym ryzykiem wiążą się tłumaczenia mające status autorytatywnych, które umożliwiają "funkcjonowanie mechanizmu prawa w więcej niż jednym języku” (cf. Šarčević 2000). Dotyczy to przede wszystkim tłumaczeń prawa wielojęzycznego, jak np. prawa unijnego stanowionego w 23 językach urzędowych Unii Europejskiej, którego wersje językowe mają taką samą moc i status jak „oryginał”, na podstawie którego wykonano tłumaczenia na pozostałe języki urzędowe ${ }^{2}$. Akty prawne są klasyfikowane jako centralny i nadrzędny gatunek tekstów prawniczych (ang. primary genre), który determinuje pochodne gatunki tekstowe: gatunki wtórne (ang. secondary genres), jak np. orzeczenia sądowe, interakcja na sali sądowej; gatunki pedagogiczne (ang. enabling/ /pedagogic genres), jak np. podręczniki i rozprawy prawnicze, eseje; oraz gatunki docelowe (ang. target genres), tj. akty notarialne, dokumentacja postępowań sądowych, porady prawne, umowy (Bhatia 2006: 6-7). Błąd w tłumaczeniu aktu prawa unijnego - zwłaszcza traktatu lub rozporządzenia - powoduje, że nie ma ono jednolitego zastosowania w Unii Europejskiej. Z tego względu dużym problemem były liczne błędy w polskim tłumaczeniu acquis communautaire, jak np. „5 lat” zamiast „5 miesięcy”, „15\% tłuszczu w mleku” zamiast

${ }^{2} \mathrm{Z}$ uwagi na unijną politykę wielojęzyczności i poprawność polityczną w przypadku tłumaczeń prawa unijnego nie mówi się o „oryginale” i „tłumaczeniach”, lecz o wersjach językowych, które tworzą jeden instrument prawny mający takie samo znaczenie we wszystkich językach. W rzeczywistości angielski, francuski i niemiecki są tzw. językami roboczymi/proceduralnymi, w których przygotowuje się „oryginał”, na podstawie którego sporządzane są pozostałe wersje językowe. 
„1,5\%”, „papryka” zamiast „pieprz”, „zakazuje się przywozu” zamiast „zakazuje się wywozu". O skali problemu świadczy fakt, że już w 2005 r. na stronach Urzędu Komitetu Integracji Europejskiej opublikowano sprostowania do tłumaczeń ponad 300 aktów prawnych (Uhlig 2005). W międzyinstytucjonalnej procedurze oceny tłumaczeń zewnętrznych opracowanej przez Sekcję Tłumaczeń Zewnętrznych przy Parlamencie Europejskim błędom w tłumaczeniu przypisuje się niski lub wysoki wskaźnik znaczenia. $Z$ niedokładnym przekazem informacji wiążą się bezpośrednio dwie kategorie błędu: błąd w tłumaczeniu (SENS) i pominięcie (OM). W pierwszym przypadku niski wskaźnik wagi błędu dotyczy zmiany znaczenia zdania bez żadnych konsekwencji prawnych; natomiast wysoki wskaźnik obejmuje poważne zmiany znaczenia zdania lub zmianę skutku prawnego ważnej klauzuli. Analogicznie w drugim przypadku błąd o niskim wskaźniku znaczenia to pominięcie, które nie wpływa na ogólną zrozumiałość tekstu, a błąd o wysokim wskaźniku oznacza pominięcie (lub pozostawienie w języku źródłowym) fragmentu oryginału (paragrafu, frazy, tabeli itp.), które zmienia znaczenie zawarte w tekście źródłowym. O wadze dokładnego przekazu informacji w przypadku tłumaczeń aktów prawa unijnego świadczy fakt, że w międzyinstytucjonalnej karcie oceny w pozostałych kategoriach (terminologia, wykorzystanie materiałów pomocniczych, jasność i rejestr, gramatyka, interpunkcja i ortografia) wysoki wskaźnik błędu odnosi się zawsze do błędów, które skutkują zmianą znaczenia, np. błąd interpunkcyjny zmieniający znaczenie zdania, całkowicie niejasno sformułowane zdanie, którego zrozumienie jest kluczowe dla prawidłowego stosowania aktu prawnego itp.

Dokładność tłumaczenia jest również ważna w innych typach tekstów prawniczych, a w szczególności w tłumaczeniach uwierzytelnionych wykonywanych przez tłumaczy przysięgłych na zlecenie organów, podmiotów gospodarczych i osób prywatnych. Tłumaczenia te są poświadczane własnoręcznym podpisem tłumacza za zgodność z oryginałem. W tej grupie tekstów najważniejsze są tłumaczenia wykonywane dla organów w sprawach karnych, np. pisma sądowe, materiały dowodowe czy zeznania, które stanowią środek komunikacji pomiędzy organem a zatrzymanym, aresztowanym lub oskarżonym i mogą mieć wpływ na jego prawa.

Problemy związane $\mathrm{z}$ naturalnością tłumaczenia ( $\mathrm{w}$ tym jego poprawnością językową) mają mniejszą wagę i mniej poważne konsekwencje. W większości przypadków sporadyczny błąd interpunkcyjny, gramatyczny czy frazeologiczny nie uniemożliwi podejrzanemu skorzystania w pełni z przysługujących mu praw ani nie będzie podstawą do wszczęcia postępowania karnego przeciwko tłumaczowi. Biuletyn TEPIS-u w odniesieniu do tłuma- 
czeń poświadczonych stwierdza: „Nieliczne literówki w tłumaczeniu uwierzytelnionym są dopuszczalne, jeśli nie występują $\mathrm{w}$ istotnych elementach tekstu (nazwiska, imiona, daty, numery itp.), innych elementach, których zniekształcenie nie powoduje zmiany sensu lub jeśli z innych powodów nie przeczą zasadzie wierności tłumaczenia i nie mogą stać się przyczyną odrzucenia tłumaczenia przez urząd" (Kierzkowska 2010: 25). Należy jednak podkreślić, że tłumaczenie dobrej jakości - tłumaczenie profesjonalne - powinno być wolne od takich błędów. Tłumacz ma obowiązek dbania o poprawność językową i eliminowania interferencji z języka źródłowego przez zapewnienie dopasowania tekstowego tłumaczenia do innych funkcjonalnie podobnych tekstów w języku docelowym. Duży napływ tłumaczeń do języka, który nie jest językiem dominującym, jak np. obserwowany obecnie napływ do języka polskiego tłumaczeń specjalistycznych z języka angielskiego, może w dłuższej perspektywie prowadzić do zubożenia języka docelowego, który staje się „bezbarwną imitacją języka źródłowego” (Cronin 2003: 147).

Waga kryterium naturalności tłumaczenia jest w dużej mierze uzależniona od celu tłumaczenia. Jest ona znacznie wyższa w przypadku tłumaczenia materiałów, które nie tylko informują, ale mają również charakter perswazyjny, jak np. strony internetowe kancelarii prawniczych, oferty i innego rodzaju teksty, które służą budowaniu wizerunku w komunikacji z klientem lub pozyskaniu zlecenia. Tłumaczenie niskiej jakości, wywołujące u odbiorcy wrażenie „trzeciego języka”, nie przekonuje o wysokim profesjonalizmie strony, nie spełnia więc zamierzonego celu.

\section{Podsumowanie i wnioski}

Podsumujmy dotychczasowe rozważania. Jakość tłumaczenia specjalistycznego jest pojęciem skalarnym i jest sumą kilku skorelowanych ze sobą elementów. Zgodnie z zaleceniami normy PN-EN 15038 do jakości tłumaczenia należy podchodzić holistycznie, dbając o jej zapewnienie na wszystkich etapach świadczenia usługi tłumaczeniowej. Istotnym etapem procedury zapewniania jakości jest obowiązkowa weryfikacja tłumaczenia przez innego tłumacza (zasada dwóch par oczu). Za wyznaczniki jakości w tłumaczeniu prawnym i prawniczym można uznać w zakresie relacji ekwiwalencji dokładność przekazu informacji zawartych w tekście źródłowym, bez zmian znaczenia i opuszczeń, a także prawidłowe i spójne zastosowanie terminologii specjalistycznej, która jest nośnikiem wiedzy. To właśnie dokładność przekazu ma w przypadku tłumaczeń prawnych i prawniczych wagę nad- 
rzędną, a błędy w tym zakresie mają najpoważniejsze konsekwencje. Z uwagi na ryzyko niedokładnego przekazu informacji zalecana przez normę PN-EN 15038 procedura zapewniania jakości z obowiązkową weryfikacją przez innego tłumacza wydaje się idealnie dopasowana do specyfiki tłumaczeń prawnych i prawniczych. W zakresie relacji dopasowania tekstowego za wyznacznik jakości przyjmuje się naturalność tłumaczenia osiąganą dzięki poprawności gramatycznej, leksykalnej, frazeologicznej, ortograficznej i stylistycznej. Waga relacji różni się i zależy od celu i statusu tłumaczenia oraz jego grupy docelowej. Tłumaczenie prawnicze wysokiej jakości powinno być i wierne, i piękne.

Warto na zakończenie podkreślić, że obowiązujący w Polsce tryb wykonywania tłumaczeń poświadczonych - mimo iż na tle innych krajów europejskich należy go uznać za postępowy - nie spełnia wymogów normy europejskiej w zakresie procedur zapewniania jakości. O ile w nadmiarze spełnione są wymagania dotyczące kwalifikacji tłumaczy, o tyle brakuje obowiązkowej weryfikacji jakości tłumaczenia przez innego tłumacza, która polegałaby na porównaniu tekstu docelowego ze źródłowym pod kątem dokładności przekazu informacyjnego. Chociaż obowiązkowa weryfikacja tłumaczenia wiązałaby się z dodatkowym kosztem dla Skarbu Państwa i wydłużałaby proces tłumaczenia dokumentów, powinna być wprowadzona w przypadku tłumaczeń dla organów. Pomimo presji czasu weryfikacja tłumaczeń jest stosowana przez rzetelne biura tłumaczeń w przypadku klientów komercyjnych, tym bardziej byłaby korzystna dla organów, zwłaszcza gdy błąd w tłumaczeniu może działać na niekorzyść podejrzanego, jak w przypadku opisanym na wstępie.

\section{Literatura}

Alcaraz Varó, E., Hughes, B., 2002, Legal Translation Explained, Manchester, St. Jerome.

Baker, M., 1996, „Corpus-based translation studies: the challenges that lie ahead”, [w:] Terminology, LSP and Translation. Studies in Language Engineering in Honour of Juan C. Sager, H.L. Somers (red.), Amsterdam-Philadelphia, John Benjamins, s. 175-186.

Bhatia, V.K., 2006, „Legal Genres”, [w:] Encyclopedia of Language and Linguistics, t. 7, K. Brown (red.), Oxford, Elsevier, s. 1-7.

Biel, Ł., 2010, „Corpus-Based Studies of Legal Language for Translation Purposes: Methodological and Practical Potential", [w:] Reconceptualizing LSP. Online proceedings of the XVII European LSP Symposium 2009, 
C. Heine, J. Engberg (red.), Aarhus, http://www.asb.dk/fileexplorer/fetchfile.aspx?file=16841 (dostęp: 9 lipca 2010 r.).

Biel, Ł., 2011, „Training translators or translation service providers? EN 15038:2006 standard of translation services and its training implications", Journal of Specialised Translation, 16, s. 61-76.

Bonthrone, R., Fry D., 2004, „High-quality translation - the new localization paradigm", [w:] Lisa Best Practice Guide: Quality Assurance - the Client Perspective, The Localization Industry Standards Association, s. 26-29.

Chesterman, A., 1997, Memes of Translation. The Spread of Ideas in Translation Theory, Amsterdam-Philadelphia, John Benjamins.

Chesterman, A., 2004, „Hypotheses about translation universals”, [w:] Claims, Changes and Challenges in Translation Studies. Selected contributions from the EST Congress, Copenhagen 2001, G. Hansen, K. Malmkjær, D. Gile (red.), Amsterdam-Philadelphia, John Benjamins, s. 1-13.

Cronin, M., 2003, Translation and Globalization, London, Routledge.

Kenny, D., 1998, „Equivalence”, [w:] Routledge Encyclopedia of Translation Studies, M. Baker (red.), London-New York, Routledge, s. 77-80.

Kierzkowska, D. (red.), 2005, Kodeks tłumacza przysięgłego z komentarzem, Warszawa, Wydawnictwo Tepis.

Kierzkowska, D., 2010, „Problemy praktyki zawodowej tłumacza przysięgłego, Biuletyn TEPIS, nr 72, Warszawa, s. 24-26.

Kotler, P., Keller, K.L., 2006, Marketing Management, wyd. 12, New Jersey, Pearson.

Kubacki, A.D., 2008, „Odpowiedzialność zawodowa tłumaczy przysięgłych”, [w:] Język, komunikacja, informacja, P. Nowak, P. Nowakowski (red.), Poznań, Sorus, s. 149-161.

Martin, T., 2007, „Managing risks and resources: a down-to-earth view of revision", Journal of Specialised Translation, 8, s. 57-63.

Mauranen, A., 2006, „Translation universals”, [w:] Encyclopedia of Language and Linguistics, t. 13, K. Brown (red.), Oxford, Elsevier, s. 93-100.

PN-EN 15038 Usługi tłumaczeniowe - Wymagania dotyczące świadczenia ustug, 2006, Warszawa, Polski Komitet Normalizacyjny.

Poznański, P., 2010, „Taniej nie będzie, bo zawiódł tłumacz?”, Gazeta Wybor$c z a$ z 19 lutego 2010 r., s. 32.

Pym, A., 2004, „Text and risk in translation”, http://www.tinet.cat/ apym/online/translation/risk_analysis.pdf (dostęp: 9 lipca 2010 r.).

Szymowski, L., 2010, „300 tys. zł "wyparowało" z powodu "zmęczenia»", http://wiadomosci.onet.pl/2122144,11,300_tys_zl_wyparowalo_z_powodu_zmeczenia,item.html (dostęp: 2 lutego 2010 r.). 
Šarčević, S., 2000, „Legal Translation and Translation Theory: a Receiveroriented Approach", Genève, Actes, www.tradulex.org (dostęp: 4 sierpnia 2008 r.).

Tymoczko, M., 2005, „Trajectories of Research in Translation Studies”, Meta L, 4, s. 1082-1097.

Uhlig, D., 2005, „Błąd na błędzie w tłumaczeniach unijnych aktów”, Gazeta Wyborcza, http://wyborcza.pl/1,75248,2485538.html (dostęp: 9 lipca 2010 r.).

\section{Akty prawne}

Rozporządzenie Ministra Sprawiedliwości z dnia 24 stycznia 2005 r. w sprawie szczegółowego sposobu przeprowadzenia egzaminu na tłumacza przysięgłego (Dz.U. z 2005 r. Nr 15, poz. 129).

Ustawa z dnia 25 listopada 2004 r. o zawodzie tłumacza przysięgłego (Dz.U. z 2004 r. Nr 273, poz. 2702).

Wniosek decyzja ramowa Rady w sprawie prawa do tłumaczenia ustnego i tłumaczenia pisemnego w postępowaniu karnym (KOM/2009/0338 wersja ostateczna - CNS 2009/0101).

\section{Quality of legal translation in light of PN-EN 15038 standard of translation services and hypothesis of translation universals}

\section{Summary}

The paper discusses the quality of legal translation under the EN 15038 standard of translation services and the hypotheses of translation universals. The standard, Translation services - Service requirements, offers a holistic approach to quality at all stages of translation service provision, viewing translation proper as one of the stages only. It specifies quality assurance procedures, one of which is obligatory revision of translation by another translator which involves a check of the target text (TT) against the source text (ST), i.e. "the four-eye principle". Chesterman's division of translation universals into S-universals and T-universals raises our awareness of two inseparable sides of specialised translation: the equivalence relation (the ST-TT relation) and the relation of textual fit between the TT/translationese and naturally occurring non-translated target language. The equivalence relation, which is of priority in legal translation, involves the accuracy of information transfer as well as adequate and consistent use of specialised terms. Given the risk of failure to transfer the information content of the ST to the TT, the independent revision requirement seems to 
be perfectly suited to legal translation, in particular translation of the law and certified translation. The relation of textual fit concerns naturalness of translation and is achieved through grammatical, lexical, phraseological, typographical and stylistic correctness. The weight of the two dimensions depends on the purpose and status of the translation and its target group. 